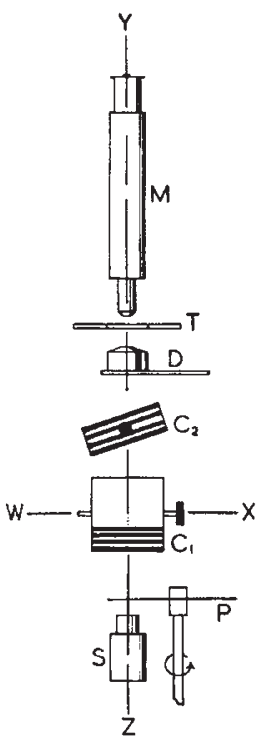
Fig. 3. Flicker dichro$T$, stage; $D$, phase: $T$, stage; $D$, phase pile of glass plates which can rotate about axes $W X$ and $Y Z ; C_{2}$, s'milar compensator to eliminate background flicker if necessary ; $P$. rotating 'Polaroid' disk ; $S$, light source

small amounts of dichroism to be detected in objects just within the resolving power of the light microscope. A compensator $\left(C_{1}\right)$ can be introduced to eliminate flicker in a dichroic object. The position and angle of tilt of the pile of glass plates, in the compensator, give the sign and magnitude of the dichroism. To test whether any dichroism was present in vivo, salivary glands of Chironomus and Drosophila were mounted as before in $0.14 M$ salt solution and observations made on a particular chromosome in an intact nucleus. The vital stain was allowed to diffuse into the chromosomes and, when a sufficient concentration had been reached, flicker was observed in the chromosome. The sign of the dichroism, when compared with the nucleoprotein model, indicated the presence of longchain molecules lying parallel to the length of the chromosome thread. The dichroism was distinct in the lightly

banded regions.

The results of the swelling and dichroism experiments, when combined with the evidence of D'Angelo ${ }^{6}$ that the fresh chromosomes can be stretched reversibly up to five times the original length in the nucleus, indicate the presence of an orderly folding of molecules within the chromosome. The structure contains regions with a parallel arrangement of long-chain molecules, recalling somewhat the type of organization found in crystalline globular proteins?

Further similar investigations on a variety of animals and plants are in progress.

Mention should be made of two short communications concerning dichroic phenomena which have appeared since completion of the above experiments. Oriented nucleoprotein fibres have been prepared by White and Elmes ${ }^{8}$ which show dichroism on staining with toluidine blue and other dyes. Ruch ${ }^{9}$ mentions weak ultra-violet dichroism in the bands of Chironomus chromosomes. Details about whether the specimen was fresh or fixed and the sign of the dichroism are, however, not given.

We are grateful to Prof. A. Haddow for his interest in this work. We should like to thank Mr. F. E. Speed for his help in the photography, and Dr. M. Bird, who supplied the Drosophila larvæ. One of us (A. R. G-A.) is indebted to the Lady Tata Memorial Trust for the award of an International Research Fellowship and to the Atomic Energy Commission, Government of India, for permission to carry out work at the Chester Beatty Research Institute. This investigation has been supported by grants to the Royal Cancer Hospital and Chester Beatty Research Institute from the British Empire Cancer Campaign, the Jane Coffin Childs Memorial Fund for Medical Research, the Anna Fuller Fund, and the National
Cancer Institute of the National Institutes of Health, U.S. Public Health Service.

[Feb. 16.

${ }^{1}$ Koller, P. C., Proc. Roy. Soc., B, 118, 371 (1935).

2 Caspersson, T., and Schultz, J., Nature, 142, 294 (1939).

${ }^{3}$ Schmidt, W. J., Chromosoma, 2, 86 (1941).

- Butler, J. A. V., and Ambrose, E. J. (in the course of publication).

${ }^{5}$ Frazer, M. J., and Frazer, R. D. B., Nature, 167, 761 (1951).

- D'Angelo, E. G., Biol. Bull., 90, 71 (1946).

'Perutz, M. F., Proc. Roy. Soc., A, 195, 474 (1949). Kendrew, J. C., ibid., 201, 62 (1950). Elliott, A., and Ambrose, E. J., Faraday Soc. Disc., No. 9, 246 (1950). Carlisle, C. H., and Scouloudi, H., Proc. Roy. Soc., A, 20\%, 496 (1951).

${ }^{8}$ White, J. C., and Elmes, P. C., Nature, 169, 151 (1952).

'Ruch F., Exp. Cell. Res., 2, 680 (1951).

\section{A WAR-TIME FISHERY}

\section{By DR. L. HARRISON MATTHEWS Zoological Society of London}

CJ.SH of many species abound in the waters of the Bristol Channel, and fisheries have existed on its shores from prehistoric times. Nearly all the commercial fishing is done on the foreshore with 'fixed engines'-nets and traps of various sorts fastened to stakes and visited by the fishermen at low tide. The great rise and fall of tide in the Bristol Channel makes this sort of fishing possible; the gear is set on dry land and fish are brought to it by the tide.

The fisheries of the Bristol Channel, except the salmon fisheries, have been declining for the past fifty years and have now only a fraction of their former importance. In 1851 it was estimated that the annual value of the fisheries between Burnhamon-Sea and Weston-super-Mare was $£ 10,000$; but now the value of the fish taken is too small for inclusion in official statistics. The decline of the fisheries was largely due to the development of the great fishing ports, which send regular supplies of deep-sea fish to all parts of the country, so that the smaller supplies fluctuating with the seasons are crowded out of the market.

In the period between the two World Wars the last remaining fishery of any importance was the swing-net fishery for sprats. Swing-nets are bag-or stocking-shaped nets buoyed and moored in the tideway. The net is extended by two spars at the mouth, the upper one of wood and the lower one of iron which keeps the mouth open by its weight. The spars are made fast by bridles to a mooring line, one end of which is fixed to a chain held on the bottom by two 30-cwt. concrete sinkers; the other end of the mooring line is buoyed at the surface, usually with a cask. The net swings with the tide so that the mouth always faces the stream and fishes both on the ebb and the flood. A tripping line made fast to the lower spar runs to the buoy through a thimble on the upper spar. When the net is visited by the boat at slack water, the tripping line is hauled up, closing the net and bringing it to the surface, and - the cod end is brought aboard and emptied. The net is about $40 \mathrm{ft}$. long and its mouth is $16-18 \mathrm{ft}$. square. The chief catch of swing-nets is sprats, with variable numbers of whiting, small cod, dabs, flounders, thornback and conger, and some shrimps. The bottom fish are caught while the net fishes near the bottom when the tide runs with its greatest force. The fishing season lasts from early October to the end of January (occasionally a month or six weeks longer). 
The swing-nets used in the Bristol Channel are made up by the fishermen from lengths of machinemade netting specially braided to order for this fishery at the factory. The specification is 70/900, hitchings every $2 \mathrm{ft}$. (between the pieces of machinemade net), seven 4's, one each of 5's up to 20's or more. The net is heavily headed with trawl twine and set in by the third. The tail is straight and 70/70. The mesh increases from 1 in. at the tail to $1 \frac{1}{8}$ and $1 \frac{1}{4}$ in., finishing with $1 \frac{1}{2}$ in. for the last few rounds at the mouth, which measures 21 yd. round. The size of the twine used is No. 20 to No. 15 (local designation). Each swing-net is fished for one week at a time and is then brought ashore for barking with cutch. The life of a net is reckoned at five years, and its pre-war price was about $£ 7-£ 10$. The nets used at spring tides are rather smaller than those used at neaps because the larger net will not stand the great weight of the current at spring tides. Swing-nets were introduced about 1880 , and to a large extent have supplanted nets of similar shape set on poles planted in the ground on the foreshore and visited by the fishermen at low tide. They have the advantage of fishing on both ebb and flood, whereas the fixed nets fish only on the ebb.

Swing-nets have been in use at several places on the English coast of the Bristol Channel; but since about 1935 they have not been used elsewhere than at Weston-super-Mare. Most of the men now or recently engaged in fishing are at least middle-aged; they say the younger generation is unwilling to work as hard as the occupation requires. Now that short hours of work and a high standard of living are general, the younger men will not enter this arduous calling, and when they are out of work unemployment benefit supports them so that they are not forced into any work they can find to save themselves from starvation. The calling requires much specialized knowledge in many directions, knowledge that is not picked up casually. The management of boats-some of the fishermen even build their own-the making and setting of nets and so on, are learned only slowly and by experience. Temperament has much to do with making successful fishermen, most of whom have considerable independence of spirit and a liking for the way of life, hard as it is.

The fine mesh of swing-nets takes great quantities of fish too small for the market. The catch of sprats is culled and only the larger fish are marketed, so that a great quantity of undersized sprats, cod, whiting, and flat-fish with small fish such as gobies, pout, poor cod and other unmarketable species is thrown away. The quantities of small cod and whiting 4-6 in. in length were very large during the season 1939-40. It had been the practice to throw away all this mass of undersized fish, with the exception of a limited amount of undersized sprats which were used as garden manure. It appeared possible that these fish might be of some use to the fish-paste industry, and contact was therefore made with a factory in Somerset that was engaged in making preserved foodstuffs. The factory was interested in the proposal to make use of this fish because its normal supplies were curtailed owing to the War.

The usual raw material used as the basis of fishpastes was canned salmon, which came to the factory ready cooked. The factory thus had no experience of dealing with raw fish, and it was necessary to make experiments to find if it could be used. The bones of canned salmon, which is already cooked, are soft,

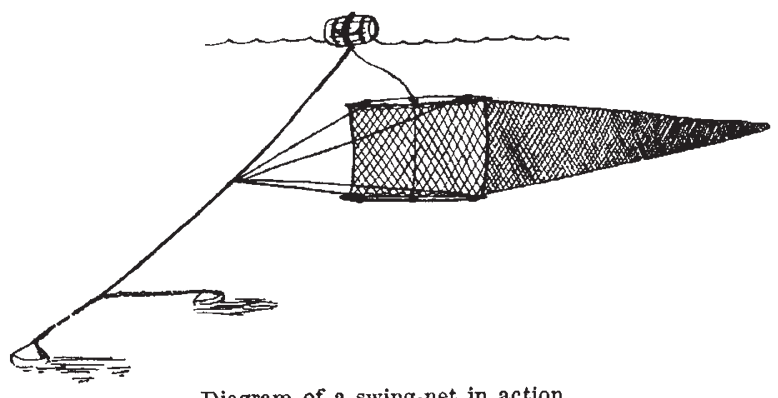

Diagram of a swing-net in action

so that the entire contents of the cans can be ground in mills to form the paste. After the paste is made and packed in pots, it is sterilized in autoclaves with steam under pressure. It seemed possible that the autoclaves might be used for cooking the raw fish; they were tried and the method was successful. The fish were packed on wire mesh trays to a depth of two or three inches, stacked in the autoclave, and given from $10-20 \mathrm{~min}$. cooking at $120^{\circ} \mathrm{C}$. This not only cooked the meat but also softened the bones, finrays and scales, so that the cooked fish could be ground in the mill without further treatment. It was found that milling produced a paste of good smooth consistency and excellent flavour. Fish of mixed species could be used, and there was no need for scaling, boning or gutting them. The paste after milling required only the addition of diluent, salt, spices and dye, and a minimum of shrimp or salmon meat. The product was packed in pots, autoclaved, sealed and marketed as "savoury fish paste containing salmon [or shrimp] with other fish".

The factory was put into touch with some of the Weston-super-Mare fishermen, who at once began sending it regular supplies of 'trash'-mixed small fishes of all kinds. The factory offered 10s. a cwt. f.o.r. at Weston-super-Mare, and at first took 3 cwt. a day four days a week. When it was shown that the fishing season lasts only for the winter months. the factory increased its consumption and endeavoured to fill part of its summer requirements by storing the fish, both in salt and in cold store. It then took 3 cwt. a day at $10 \mathrm{~s}$. a cwt. five days a week, and offered $7 s, 6 d$. a cwt. for any quantity in addition. As a result, it was sent an additional 3-4 cwt. daily at the lower price, an arrangement which appeared to be satisfactory to the fishermen.

The sprat fishery during the winter of 1939-40 was not good; but great quantities of small cod and whiting were taken, together with much other small fish. This new outlet for their formerly useless catches was therefore much appreciated by the men who took advantage of it. Their dealings with the factory were very satisfactory to them; they were paid promptly every week for the weight of fish received by the factory, which tallied with that dispatched. Empties were returned promptly, and a further supply of them was provided by the factory when the quantity of fish taken daily was increased.

This arrangement was completed only towards the end of the 1939-40 fishing season; but in the last few weeks of that season between 12 and 15 tons of fish that would otherwise have been wasted were utilized. The arrangement was maintained in the following years during every fishing season until that of 1949-50, and very considerable quantities of fish were thus used for food. In the season 1948-49, however, the factory reported a considerable falling- 
off in the demand for fish pastes, and at the end of the 1949-50 season it cancelled the arrangement. Since that season no further fish from the Bristol Channel swing-net fishery has been used by it for manufacturing purposes.

Even when the arrangement was in full operation, however, the fishermen frequently took larger quantities of fish than the factory could deal with, and the surplus was then sold to a local firm of poultry-food manufacturers. Nevertheless, at the height of most seasons this additional outlet was not able to absorb all the fish caught and the remainder was sold to a firm engaged in boiling pig-swill. The poultry-food manufacturers continued taking supplies until the season $1950-51$, when their demand decreased and finally stopped. The remaining outlet, the firm boiling pig-swill, has always been able to take as much as the fishermen wished to dispose of but at very small prices.

Owing to the cessation of demand from the fishpaste factory and the poultry-food manufacturers, the effort put into the fishery in the season 1950-51 was much less than usual; such catches as were made were small and disappointing so that the season was counted a complete failure by the fishermen. The season just past, 1951-52, has also been a complete failure. The few nets put out at the beginning of the season caught practically nothing and the full fleets were not fished at all. A net was set at the beginning of October and was kept fishing on and off until into January; but on no occasion were more than about $10 \mathrm{lb}$. of sprats landed. The fishermen reported that it was the worst season ever known, and that they are at a loss to understand the reason for it.

The life of the industry thus lasted just ten years, and although the undertaking was never great it helped to eke out food supplies and to vary the monotonous diet of war-time ; it was also a valuable source of income to enterprising fishermen. The factories are now able to obtain their raw materials from sources less liable to seasonal fluctuation, materials which, being partly manufactured, need less work done upon them. The ranks of the skilled fishermen are not being filled by younger men; the long, irregular hours of work for uncertain returns are very unattractive in times of full employment when easy work can be obtained by all. The old hands are discouraged by the failure of recent seasons and the lack of demand for their catches, and young men will not consider such hard work. Thus, high freight charges, and the frustration of enterprise by permits and regulations, combined with two very bad seasons, seem to have completed the extinction of this interesting local industry.

\section{THE ORIGIN OF ASTRONOMY}

THE George Darwin Lecture of the Royal Astronomical Society was given on April 13, 1951, at Burlington House, London, by Prof. Antonie Pannekoek, professor of astronomy in the University of Amsterdam, on the occasion of the award to him of the Society's Gold Medal for his work in astrophysics and on the structure of the galactic universe. Prof. Pannekoek's lecture, which has now been published*, was on "The Origin of Astronomy".

Starting with primitive astronomy, he said that he believed that the origin of this was not due to the

* Mon. Not. Roy. Astro. Sor., 111, No. 4 (1951). beauty of the silent heavens but to utilitarian motives. $\mathrm{He}$ agrees with Schiaparelli that economic necessities were at the root of man's astronomical as well as of his physical and chemical knowledge. Among such necessities there was the need for finding direction by land and sea, and history affords many instances of man using the celestial luminaries to guide him. Even so-called backward races like the Polynesians were well acquainted with the stars, and they steered their vessels by means of the rising and setting of the heavenly bodies. Of even greater importance than for navigation was the application of astronomy for time reckoning, and so crude forms of almanacs came into existence which enabled farmers to regulate their work according to seasonal life-periods of animals and plants; to-day primitive peoples are able to observe solar phenomena, such as the solstices, by noticing the times of extreme rising and setting at points of the horizon marked with stones. The helical rising of certain stars, indicating the time for sowing, just as the helical rising of Sirius in June foretold to the ancient Egyptians the flooding of the Nile, is still used by backward races even if they have come into contact with the white man. The use of the moon as the measure of time among many ancient races is well known, and the sacred books of some of these allege that the moon was created for this very purpose. Although a certain amount of astronomical knowledge characterized prehistoric man, this knowledge was frequently in the hands of old people or priests; but it would be a misnomer to call it astronomical science. Science, in the real sense of the word, arose when man entered into the stage of civilization, and the transition from barbarism to civilization was marked by the invention of script.

About five thousand years ago the first civilizations arose in the fertile plains of Egypt, Mesopotamia, India and China, and in time a strong State power grew up to defend the inhabitants against warlike tribes who found only meagre living in their surrounding mountains and deserts. Thus arose an army to protect the farmers, and beside the military power stood the civil officials ; with the appearance of these ruling classes with their wealth and luxury new needs gave rise to developments of refined arts and spiritual culture. In these circumstances the conditions were present for the introduction and spreading of script. The effect of the new conditions on astronomy was far-reaching, because the use of script added enormously to the powers of the priests to whom were entrusted the regulation of time as well as many other important State responsibilities. Ancient inscriptions show the leading part that the priesthood took in settling by means of the heavenly bodies the times of sowing and reaping. Naturally, the work for utilitarian purposes did not end there, and so a number of constellations were recorded and also the brightest of the planets; later astrology arose, though at first it was largely limited to the significance of celestial phenomena for national events-unlike this superstition at present when it is the cult of the individuals who may be more numerous than many astronomers suspect. How did these ancient peoples, Babylonians, Egyptians, Assyrians, etc., without knowing much about scientific aims, build up a scientific theory?

As Prof. Pannekoek shows, this was made possible for astronomy by the occurrence of simple and striking periodicities in the celestial phenomena, and among such phenomena lunar eclipses played a prominent part as their prediction is comparatively 